\title{
The Policy of the Military District Command 0609 / Cimahi in Helping Local Governments to Handle Covid-19 Pandemic
}

\author{
Agus Subagyo* \\ Faculty of Social and Political Sciences \\ General Achmad Yani University \\ Cimahi, Indonesia \\ *subagyoeti@yahoo.com.au
}

\begin{abstract}
This study aims to analyse the policy of the Indonesian Army (Military District Command 0609/Cimahi) in assisting the Regional Government of Cimahi City and West Bandung Regency in dealing with the Covid-19 pandemic which has been endemic in Indonesia since March 2020. The research questions posed are how the form of policies formulated and implemented by Military District Command 0609/Cimahi in dealing with the Covid-19 Pandemic in the Cimahi City and West Bandung Regency areas? To answer these research questions, a social control theory analysis framework was used. The research method used is a qualitative method with data collection techniques in the form of observation, interviews, and literature studies. The results showed that the policies formulated and implemented by Military District Command 0609/Cimahi in dealing with the Covid-19 Pandemic in the Cimahi City and West Bandung Regency areas were realized in the following stages: (1) preventive activities with socialization of a clean and healthy lifestyle, the $3 \mathrm{M}$ campaign, namely washing hands, wearing masks, maintaining distance, inviting people to maintain stamina by doing regular exercise, and distributing masks; (2) repressive activities by conducting patrols to control public discipline, giving warnings not to crowd, and giving sanctions / punishments to health protocol violators; (3) curative with activities to pick up positive Covid-19 patients, carry out the isolation process for Covid-19 patients at the hospital, and treat Covid-19 patients at the Dustira Hospital.
\end{abstract}

Keywords—policy, army, pandemic, Covid-19, Cimahi

\section{INTRODUCTION}

In the perspective of national defence policy, threats can be in the form of military and non-military threats. A military threat is a threat originating from abroad in the form of foreign army forces attacking an area of the State. Non-military threats include food threats, economic threats, environmental threats, energy threats, and health threats [1]. The Covid-19 pandemic is a health threat that is classified as a non-military threat, which seriously endangers human security and the national security of all countries in the world, including Indonesia.
The Covid-19 pandemic that originated in Wuhan, China, since December 2019 and spread to all regions of the world in early 2020 and entered Indonesia in real time in March 2020, has shaken all aspects of the socio-economic life of the Indonesian people [2]. As a state apparatus, the army is ordered by the Jokowi government to assist the government and local governments in dealing with the Covid-19 pandemic. This is in accordance with Law Number 34 of 2004 concerning the Indonesian National Army, in particular Article 7, which states that in carrying out its duties, the Army National Indonesia held War Military Operations and Military Operations Other Than War. Military Operations Apart from the War, one of them is helping to cope with the consequences of natural disasters, displacement and providing humanitarian assistance.

In carrying out the mandate of the law, the Military District Command 0609 / Cimahi, which is a territorial unit of the Indonesian Army, held an assisting operation to the Regional Government in dealing with the Covid-19 pandemic. The Military District Command 0609 / Cimahi, which oversees Cimahi City and West Bandung Regency, believes that the Covid-19 pandemic is a non-military threat that threatens Indonesia's national security so that they are doing their best to help the local governments of Cimahi City and West Bandung Regency to cope with the Covid-19 pandemic in the community, together with the Indonesian Republic Police, the Health Service, doctors, health workers, and other humanitarian volunteers who are members of the Covid-19 task force.

This research also continues the research conducted by the Indonesian Army Command and Staff School, with the title: "The Role of the Army Regional Command Unit in Handling the Covid-19 Pandemic in the New Normal Era" [3]. Seskoad's research took a sample of 10 Military Regional Commands in Indonesia so that it is wider. While this research is more focused and detailed because it only takes the research object at the Military District Command 0609 / Cimahi, so it is hoped that the results of this research are clearer, more focused, and detailed. 
The research question posed is what is the concrete form of the policies formulated and implemented by the Military District Command 0609 / Cimahi in dealing with the Covid-19 pandemic in the Cimahi City and West Bandung Regency areas? In addition, it will also be analysed and explained the obstacles faced by the Military District Command 0609 / Cimahi in assisting the Regional Government of Cimahi City and West Bandung Regency in handling the Covid-19 pandemic. It is hoped that this research can produce research findings / research novelties that have never been researched or found by other research so that it can be used as input and policy advice for related parties, especially the Army and Local Governments throughout Indonesia

\section{LiterATURE REVIEW}

To analyse the policy of the 0609 / Cimahi Military District Command in assisting the Regional Government of Cimahi City and West Bandung Regency in dealing with the Covid-19 pandemic, a theoretical conceptual framework is needed which will become the blade of analysis so that the analysis presented is systematic, logical and rational. The theoretical conceptual framework used is social control theory.

Social control theory states that efforts and methods to regulate, manage, and limit the movement of people in society during situations and conditions in emergency situations due to the threat of diseases and other epidemics that threaten individuals, groups, and society in general is through the policy stages: preventive, repressive, and curative [4].

The Preventive policies are activities carried out to prevent or so that something dangerous happens. Every effort and method are made so that potential threats do not become real and do not occur because they will endanger the safety of the community. The Repressive policies are steps that are implemented to impose sanctions or punishments on people and groups who violate the rules and regulations set out to create social order. The curative policy is in the form of efforts to treat and treat individuals / citizens who are affected or stricken by a disease outbreak so that it does not spread to other people or rescue people infected with a disease outbreak [5].

\section{MethodOLOGY}

The research method used in this research is a qualitative method, which is descriptive in nature. Qualitative method is a research method that looks for the meaning behind events, phenomena, and incidents, which are then narrated using words and sentences [6]. Descriptive means only visualizing the data as it is so that it will produce a systematic, objective, and valid analysis [7].

Data collection techniques in this study were carried out through in-depth interviews with competent informants, empirical observations of activities and events that occurred in the field, and documentation study through review of officially issued documents and analysis of books, journals, and internet sites.

\section{RESUltS AND DisCUSSION}

In this section on the results of research and discussion, we will explain and analyse the development of the number of Covid-19 cases in Cimahi City and West Bandung Regency, followed by policies formulated and implemented by the Military District Command 0609 / Cimahi in assisting the Cimahi City Government and West Bandung Regency dealing with the covid-19 pandemic, as well as the obstacles faced by the 0609 / Cimahi Military District Command in dealing with the Covid-19 pandemic in Cimahi City and West Bandung Regency.

\section{A. The Development of Covid-19 in Cimahi City and West Bandung Regency}

Based on 2020 data, the total population of Cimahi City reaches 555,966 people, with an area of 40.23 square kilometres [8]. The area, which only consists of 3 sub-districts, is very prone to a spike in Covid-19 cases because it is located on the border with Bandung City and is in the area of the crossing between Bandung City and West Bandung Regency. Cimahi City has been included in the red zone for 2 times, namely in August 2020 and November 2020 [9]. While the number of Covid-19 cases in Cimahi City up to December 4, 2020 can be seen in the following table 1 :

TABLE I. DATA ON THE NUMBER OF COVID-19 CASE IN CIMAHI CiTY UP TO 4 DECEMBER 2020

\begin{tabular}{|l|l|l|}
\hline No & \multicolumn{1}{|c|}{ Case } & \multicolumn{1}{c|}{ Amount } \\
\hline 1 & Aktive Confirmation (Positive) & $408(32,98 \%)$ \\
\hline 2 & Recovered & $796(64,35)$ \\
\hline 3 & Died & $33(2,67)$ \\
\hline & Total & $1.23700 \%)$ \\
\hline \multicolumn{2}{|c|}{ Source: Laporan Satuan Tugas Covid-19 Kota Cimahi }
\end{tabular}

For the West Bandung Regency area, the population in 2020 will reach $1,616,203$ people, with an area of $1,305.77$ square kilometres [10]. This region has 16 sub-districts and 165 villages with quite high risk of Covid-19 cases because it was included in the red zone in October 2020, considering that this area has many tourist attractions, such as in Lembang, Parongpong, and Cisarua Districts, so that the transmission of covid-19 is relatively fast and high because it is brought by tourists from various regions [11]. The number of Covid-19 cases in West Bandung Regency up to December 4, 2020 can be shown in the following table 2 :

TABLE II. DATA ON THE NUMBER OF COVID-19 CASE IN WEST BANDUNG REGENCY UP TO 4 DECEMBER 2020

\begin{tabular}{|l|l|l|}
\hline No & \multicolumn{1}{|c|}{ Case } & \multicolumn{1}{|c|}{ Amount } \\
\hline 1 & Active Confirmation (Positive) & $400(31,93 \%)$ \\
\hline 2 & Recovered & $627(65,36)$ \\
\hline 3 & Died & $27(2,54)$ \\
\hline \multicolumn{2}{|c|}{ Tource: Laporan Satuan Tugas Covid-19 Kabupaten Bandung Barat }
\end{tabular}




\section{B. The Policy of Military District Command 0609 / Cimahi}

In handling the Covid-19 pandemic in Cimahi City and West Bandung Regency, the Military District Command 0609 / Cimahi is to assist the local government and the police in disciplining the public to comply with health protocols and also assisting in enforcing the law against parties deemed to have violated provisions, endangering human safety, as well as threatening public safety during the Covid-19 pandemic. This is in accordance with the government policy which instructs the Indonesian National Army to help the government carry out humanitarian disaster management due to the Covid-19 pandemic, which is then followed up by the Indonesian National Army by holding medical handling operations, security operations, and logistical support operations, etc.

In this regard, the Military District Command 0609 / Cimahi, which is part of the Covid-19 task force in Cimahi City and West Bandung Regency, has implemented policies with preventive, repressive and curative stages, as stated in the theory of social control.

At the preventive policy stage, what was carried out by the Military District Command 0609 / Cimahi was conducting 3M socialization (washing hands, wearing masks, maintaining distance) in the community, campaigning for a clean and healthy lifestyle to all residents, counselling about the Covid19 virus in all community elements, guidance for the first treatment of residents with confirmed Covid-19, and conducting rapid tests, and holding PCR tests at Dustira Hospital. The following table describes the number of programs and activities carried out by the Military District Command 0609 / Cimahi in taking preventive actions during the Covid-19 pandemic.

TABLE III. The PREVENTIVE Programs AND ACTIVITIES OF THE MilitARY DisTRICT COMMAND 0609 / CIMAHI PREVENTING COVID-19 PANDEMIC UP TO 4 DECEMBER 2020

\begin{tabular}{|l|l|l|}
\hline No & \multicolumn{1}{|c|}{ Activities } & \multicolumn{1}{c|}{ Total } \\
\hline 1 & Covid-19 Socialization & 30 \\
\hline 2 & Covid-19 Campaign & 25 \\
\hline 3 & Covid-19 Counseling & 41 \\
\hline 4 & Covid-19 Guidance & 37 \\
\hline 5 & Rapid Test & 15 \\
\hline 6 & PCR Test & 8 \\
\hline & Total & 156 \\
\hline
\end{tabular}

Source: Laporan Satuan Komando Distrik Militer 0609/Cimahi

At the repressive policy stage, the Military District Command 0609/Cimahi carried out a health protocol discipline process to all elements of society and assisted the Civil Service Police and the Police in enforcing the law against parties who violated the rules and fixed procedures in health protocols during the Covid-19 pandemic. Activities carried out during large-scale social restrictions include patrolling every subdistrict / village, establishing checkpoints on highways and in crowded centres, giving warnings to crowd activities that invite crowds, giving warnings to people who violate health protocols, and give punishment to residents who do not wear masks or crowd in public places. For more details, here are the numbers of repressive activities carried out by the Military District Command 0609 / Cimahi.

TABLE IV. THE PROGRAMS AND REPRESIVE ACTIVITIES OF THE MILITARY DISTRICT COMMAND 0609 / CIMAHI PREVENTS COVID-19 PANDEMIC UP TO 4 DECEMBER 2020

\begin{tabular}{|l|l|l|}
\hline No & \multicolumn{1}{|c|}{ Activities } & \multicolumn{1}{c|}{ Amount } \\
\hline 1 & Patrol & 139 \\
\hline 2 & Establishment of Checkpoint & 69 \\
\hline 3 & Verbal Warning & 298 \\
\hline 4 & Written Warning & 183 \\
\hline 5 & Punishment & 72 \\
\hline & Total & 761 \\
\hline
\end{tabular}

Source: Laporan Satuan Komando Distrik Militer 0609/Cimahi

At the curative policy stage, the activities held by the Military District Command 0609 / Cimahi were picking up residents who were confirmed positive for Covid-19 from hospitals to hospitals and independent isolation places, guarding hospitals that treat Covid-19 patients so they don't escape. from the isolation room, securing the burial of the bodies of covid-19 patients so as not to cause a crowd of residents, sending military doctors to treat Covid-19 patients in several military hospitals and regional public hospitals, establishing an emergency hospital in the form of an emergency tent in an independent isolation area to accommodate Covid-19 patients who are not accommodated in hospitals because they are full or over capacity. In addition, the Military District Command 0609 / Cimahi also helps distribute medical equipment needed at each community health centre in all sub-districts in Cimahi City and West Bandung Regency, which is assistance from the central government and the provincial government of West Java. The following table will explain the number of curative activities held by the Military District Command 0609 / Cimahi during the Covid-19 pandemic.

TABLE V. THE PROGRAMS AND CURATIVE ACTIVITIES OF THE MILITARY DISTRICT COMMAND 0609 / CIMAHI PREVENTS COVID-19 PANDEMY UNTIL DECEMBER 4, 2020

\begin{tabular}{|l|l|l|}
\hline No & \multicolumn{1}{|c|}{ Activities } & \multicolumn{1}{|c|}{ Total } \\
\hline 1 & Patient Pick Up & 82 \\
\hline 2 & Hospital Guard & 94 \\
\hline 3 & Funeral Security & 71 \\
\hline 4 & Establishment of Emergency Tents & 12 \\
\hline 5 & Dispatch of Military Doctors & 37 \\
\hline \multicolumn{2}{|l}{ Total } & 296 \\
\hline
\end{tabular}

The programs and activities held by the Military District Command 0609 / Cimahi in helping local governments handle the Covid-19 pandemic in Cimahi City and West Bandung Regency, seen in the preventive, repressive and curative stages, have been quite optimal, where the regional governments of Cimahi City and West Bandung Regency feels very helped by the existence of Military District Command 0609/Cimahi, which is always ready and responsive if needed in overcoming the Covid-19 pandemic in the community. 


\section{The Obstacles Faced by the Military District Command 0609/Cimahi}

Although the programs and activities carried out by the Military District Command 0609 / Cimahi in dealing with the spread of the Covid-19 pandemic in Cimahi City and West Bandung Regency are quite optimal, there are still obstacles faced so far by the Military District Command 0609 / Cimahi. The constraints faced are the constraints and limitations of personnel, the minimum budget allocation constraints, and the lack of equipment / infrastructure.

The personnel limitation constraint refers to the number of personnel from the Military District Command 0609 / Cimahi which is not comparable to the population in Cimahi City and West Bandung Regency. The number of personnel is only 241 personnel, while ideally it is 419 personnel. The shortage of personnel is mostly at the village supervisory officer level, where 1 village guidance officer handles 2 or even 3 villages, especially in West Bandung Regency. In fact, ideally 1 noncommissioned officer for village guidance handled 1 village [12]. As a result, personnel who function as non-commissioned officers for village guidance must work hard to provide guidance, counselling, and outreach to the public regarding preventing the spread of covid-19.

The obstacle to the minimum budget allocation for Military District Command 0609 / Cimahi has indeed occurred long before the covid-19 pandemic. The programs and routine activities of the 0609 / Cimahi Military District Command before the Covid-19 pandemic had faced the problem of budget constraints, coupled with the covid-19 pandemic disaster which required a large budget because the Military District Command 0609 / Cimahi held assistance operations to local governments in overcoming the spread of the covid-19 virus in the community. The 2020 budget allocation for Military District Command 0609 / Cimahi reaches IDR 5 billion. However, financing for covid-19 prevention activities only reaches $\mathrm{Rp}$. 800 million alone, while the work demands and implementation of the task of handling the Covid-19 pandemic have been running for more than 8 months, which requires large funds [13]. Indeed, there is assistance from the local government of Cimahi City and West Bandung Regency, but the amount is not large and is still lacking, so that it affects the performance of all personnel in the Military District Command 0609 / Cimahi.

The problem with inadequate equipment / infrastructure owned by the Military District Command 0609 / Cimahi has become a public secret in the community. The ambulance vehicle only has 1 unit, while there are many requests from the public to accompany residents who have been confirmed positive covid-19 after the rapid test and PCR test. The number of two-wheeled vehicles for village supervisors to conduct outreach at the kelurahan or village level is also very limited. Emergency tents that are used to accommodate residents who are positive Covid-19 but cannot be accommodated in hospitals are also very limited. In fact, the demand to set up an emergency tent to function as an emergency hospital is very large considering the capacity of the hospitals in the City of
Cimahi and West Bandung Regency is already full [14]. Transport vehicles in the form of trucks for the transportation of health logistics and government-assisted health equipment to each puskesmas/ public health facilities in all sub-districts are also still limited, while the Military District Command 0609 / Cimahi always gets requests from the local government to assist in the process of sending and transporting health logistics to regional hospitals and health centres need.

Based on the description of the obstacles faced by the Military District Command 0609 / Cimahi in helping local governments overcome the spread of the covid-19 virus in Cimahi City and West Bandung Regency, it can be stated that the Military District Command 0609 / Cimahi has tried its best to help deal with the Covid-19 pandemic in Amid the shortcomings and limitations faced, both limited personnel, budget, and equipment, but with high fighting spirit, duties and responsibilities are carried out sincerely and without strings attached.

\section{CONCLUSION}

The policy of the 0609 / Cimahi Military District Command in helping local governments handle the Covid-19 pandemic in Cimahi City and West Bandung Regency is carried out through preventive, repressive, and curative stages. Preventive action is carried out by socializing health protocols (washing hands, wearing masks, maintaining distance), educating the public about the dangers of the Covid-19 virus, and community guidance in preventing the Covid-19 virus. Repressive actions are carried out by holding public disciplinary operations to comply with health protocols and to impose sanctions / punishments on violators of health protocols. Curative measures were carried out by guarding hospitals, securing the burial of the bodies of covid-19 patients, setting up emergency tents in isolation areas for covid-19 patients, and sending military doctors to health centres.

The findings of this study are the fact that there are problems faced by the Military District Command 0609 / Cimahi in dealing with the spread of the Covid-19 virus so far, namely the constraints of limited personnel, minimal budget allocation, and inadequate infrastructure / equipment, thus affecting the performance of the Military District Command 0609 / Cimahi in tackling the covid-19 pandemic.

\section{RECOMMENDATION}

Based on these conclusions, it can be recommended that additional personnel, budget fulfilment, and equipment / infrastructure procurement at the Military District Command 0609 / Cimahi be needed in order to support the performance of the Military District Command 0609 / Cimahi in handling the COVID-19 pandemic in Cimahi City and West Bandung Regency.

In addition, in order for the handling of the Covid-19 pandemic in Cimahi City and West Bandung Regency to be successful, it is necessary to empower the pentahelix model, namely the synergy and partnership model between the 
government (including the Bureaucracy, Army and Police), society (community), academics (universities), entrepreneurs (business world), and the media.

\section{REFERENCES}

[1] B. Buzan, People, States, Fear: An Agenda for International Security Studies in the Post Cold War Era. London: Harvester Whatsheaf, 1991.

[2] T.N. Nurani, Kronologi Munculnya Covid-19 di Indonesia Hingga Terbitnya Kepres Darurat Kesehatan. Merdeka.Com [Online]. Retrieved From: https://www.merdeka.com/trending/kronologi-munculnya-covid19-di-indonesia-hingga-terbit-keppres-daruratkesehatankln.html?page=1, 2 April 2020

[3] Sekolah Staf dan Komando Angkatan Darat, Peran Satuan Komando Kewilayahan TNI AD Dalam Menangani Pandemi Covid-19 Di Era New Normal. Bandung, 2020.

[4] S.R. Jouseph, Social Control. Toronto: D. Van Nostrand Company, Inc. 1951.

[5] D. Garland, "Sociological Perspectives on Punishment," Crimes and Justices, vol. 14, no. 2, pp. 41-62, 1991.
[6] A. Afifuddin and B. Ahmad, Metodologi Penelitian Kualitatif. Bandung: Pustaka Setia, 2009

[7] J.M. Lexy, Metodologi Penelitian Kualitatif. Bandung: PT Remaja Rosdakarya, 2008.

[8] Biro Pusat Statistik, Kota Cimahi Dalam Angka. Cimahi, 2020.

[9] A. Haryanto, Kota Cimahi Kembali Masuk Dalam Zona Merah Covid19. Okezone.com [Online]. Retrived from: https://news.okezone.com/read/2020/11/18/525/2312041/kota-cimahikembali-masuk-ke-zona-merah-covid-19, 19 November 2020.

[10] Biro Pusat Statistik, Kabupaten Bandung Barat Dalam Angka. Ngamprah, 2020.

[11] A.Y. Anshor, Kabupaten Bandung Barat Zona Merah Covid-19, Bupati Imbau Wisatawan Tak Berkunjung Ke Lembang. pikiranrakyat.com [Online]. Retrieved from: https://prfmnews.pikiran-rakyat.com/bandungraya/pr-131060289/kabupaten-bandung-barat-zona-merah-covid-19 bupati-imbau-wisatawan-tak-berkunjung-ke-lembang, 5 Desember 2020.

[12] Laporan Satuan Komando Distrik Militer 0609/Cimahi Tahun 2020, unpublished.

[13] Laporan Evaluasi Program Kerja dan Anggaran Komando Distrik Militer 0609/Cimahi Tahun 2020, unpublished.

[14] Laporan Peralatan dan Logistik Komando Distrik Militer 0609/Cimahi Tahun 2020, unpublished. 